\title{
Wireless Web Kids - Mobile Learning in Primary and Secondary Education
}

\author{
doi:10.3991/ijim.v3i2.749 \\ Ruben Jans and Valère Awouters \\ Limburg Catholic University College, Diepenbeek, Belgium
}

\begin{abstract}
Wireless Web Kids (WW-kids) is an approved project with financial support of the Flemish government, Economics Department. The project started in December 2007 and runs till December 2010. Main purpose is to motivate children for studying sciences and technology. In Belgium there is a lack of students studying engineering, physics, chemistry, biology, technology and informatics. The project aims to enlarge the knowledge of children in primary and secondary education in the field of ICT in general, and new technologies as mobile devices for learning in particular. In the project students will learn and study with WEB 2.0 applications, using mobile devices. After the project children will have a clear inside how mobile devices can contribute to learning and working. The project is supported by companies and research units of the University of Hasselt.
\end{abstract}

Index Terms-gps (Global Positioning System), mobile devices, mobile learning, pda (Personal Digital Assistant), WEB 2.0.

\section{BACKGROUND OF THE PROJECT}

Due to the fact that not enough students choose for studying exact sciences and engineering, companies face a shortage of labour forces. Nowadays exact sciences and technology have no special motivation anymore for younger people. Professions as researcher are seen as boring, working lonely behind a desktop. In reality these professions have made a real change last years. Researchers have also to have organizational and communicational skills. Within the global science and technological innovation policy the Flemish government spends a lot of attention to popularise science, technique and technological innovation.

\section{A. Action plan 'Science information and Innovation}

The annual action plan 'Science information and Innovation' constitute the instrument the Flemish government use to implement the policies. The budget of this action plan in 2006 was approximately 8.2 million euro. The 'Department Economic, Science and Innovation' draw up the action plan and is in charge for coordination and the follow up of it. For the realisation of the different actions, the government makes an appeal to a lot of partners. The strategic aims are to strengthen and maintain the social basis of science, technique and technology innovation.
B. The aims of the plan

The common aims of the action plan are:

- Supply information about science en technology in general and the research in particular.

- Make aware for the interest of scientific research and innovation.

- Give account for using funds from the Flemish government for this research and innovation.

- Create a kind of culture that technological innovation welcomes.

The specific aims:

- The science and technological potential of the inhabitants increase by lifelong learning

- Encourage employers to technological the innovation

- Non-used potential, girls in particular, trace

- Try to cater for a broad public

\section{Target groups}

The actions of the action plan concentrates on young people, teachers and the broad public. The most common target groups:

- Pupils primary education

- Pupils secondary education

- Teachers primary education

- Teachers Technological Education (secondary education)

- Teachers Science (secondary education)

- Students pedagogical education

- The broad public.

\section{THE PROJECT}

\section{A. Introduction}

The goal of this project is to expand the knowledge of pupils from the third grade primary education (10-12 year) about ICT in mobile technology. The use of software applications such as WEB 2.0 and mobile devices such as GPS and PDA contribute that pupils at the end of the project have a clear mind about the used ICT tools. Thanks to company visits and interviews with ICT specialists they gain insight in possible study choices and professions related to ICT. 
On the one hand the secondary education pupils will develop interactive whispering stories. This interactive whisper story is a kind of informative search in a specific region using mobile devices to give information about the history, geography, nature and culture of the region. The search will be organised in a competition.

On the other hand the primary education pupils will use this story. By visiting the region (by walking or biking) children will get questions and by search immediately online in Wikipedia and elsewhere they have to find answers, that will have to be sent back immediately.

With the support of companies and the university of Hasselt, last grade students in secondary education will develop the whisper stories and implement them in gpseditors. While the project runs the students can publish their results, impressions, reflections, ... on HasseltLokaal, the online version of the regional newspaper. The contacts with researchers, employees in companies, journalists, ... will hopefully give the students impressions of the new aspects of these professions and can motivate them for choosing studies that leads to these professions. With children of primary education the whisper stories, secondary education students made, are done with the main goal to confront very young children (10-12 years) with new technologies. The aim is to inspire them with the possibilities of new media, like i-pod, iphone, pda.

\section{B. Scientific domains}

Through the interdisciplinary character of the project a lot of scientific domains get a chance. First of all the pupils will be immersed in the world of Web 2.0 by means of company visits and introduction lessons.

The task is to get familiar with mobile technology through an interactive whispering story. Each group will develop their own story. The secondary education pupils will develop the story with the help of a software application, Mediascape. The pupils should not concentrate on one field or course but integrate other courses in their story and they need to work in teams. The pupils will gather their information and publish it on a Wiki-page. The several stories will be presented during a slot happening, a panel of judges will evaluate the stories. So it is important for the pupils to be creative, original, have good arguments and presentational skills.

The projects were pupils from technical schools work together with companies covers a large scale of domains. We couple important aspects of the story to scientific domains:

- Multimedia: the pupils will use new multimedia and technology during their search

- Information science: the pupils will make their own wiki-page about mobile technologies. They also will compare different personal environment such as Netvibes and iGoogle.

- Language: is an important domain that also belongs to scientific projects.

At least we want to emphasize that pupils will work together with companies and in team, were aspects such as planning, budget, cooperation and presentation be under discussion. This shows that these aspects also come up in technical professions.

\section{Learning elements}

The students discover WEB 2.0 tools and applications, and how these technologies are made and can be used. Developing a whisper story with pda, i-pod and i-phone asks for organizational skills for a real project, in which actual tools as iGoogle, Netvibes, Zoho-projects will be integrated. These tools are already used in real businesscontexts.

For primary education the focus lies in using the interactive whisper story. The project starts for this target group with an explanation - appropriate for their age about the basic principles of the used soft- and hardware. The accent lies on the functionality and on the use.

The core learning elements are about ICT-technology: especially multimedia and informatics. Other learning domains are history, geography, economics, and biology. These learning domains are integrated in the whisper story and the questions pupils get about.

Language is also an important domain that is part of every profession these days. Therefore Concentra was asked to be a partner in the project. Concentra is de editor of a regional newspaper but also has a very good online version, called Hasselt-Lokaal. Pupils get the possibility to make reports about the project and publish them online.

In this project pupils will learn about, with and trough the use of ICT.

\section{Implementation of the project}

For the implementation of the project in secondary education, five pilot schools were selected. Teacher will be involved within this project. First of all the teachers need some training. Not all teachers in secondary education are familiar with Web 2.0 or mobile technology. Therefore a 2 day course was developed.

During the first session the teachers get familiar with Web 2.0. Some important tools were showed and the teachers had the possibility to try things out. The second part of the first training day was about mobile technology. All teachers had there own PDA. These devices were bought by the research group and will be lend out during the whole project. So schools don't need to invest in such expensive devices. The second day was more concrete. Making a Mediascape was one of the goals during this last session. After this training the teachers must be able to help their students creating a digital story with Mediascape.

At the end of the school year all the four pilot schools present their digital story. The primary education schools will use the digital stories. Before they go outside, they will get a course about mobile devices.

\section{CONCLUSIONS}

The WW-Kids-project wants to contribute at the popularisation of sciences and technology. With students from last grade in secondary education whisper stories will be made with mobile devices. Pupils from primary education will do the project with the whisper stories, their "colleagues" in secondary education made. The cooperation with companies, university and newspaper is essential. Main goal is to motivate students - from already a very young age - for studying exact sciences and technology. In a later phase of the project it will be researched if this project can have a European dimension. 


\section{REFERENCES}

[1] Atttewel Jill (2005) Mobile Technologies and Learning, a technology update and m-learning project summary, Technology Enhanced Learning Research Centre, Learning and Skills Development Agency, http://www.m-learning.org/docs/ The\%20m-learning\%20project\%20-\%20technology\%20update \%20and\%20project\%20summary.pdf

[2] ICT op school, (2006), MOBIEL LEREN, http://www.ictopschool.net/kennis/vraagstukken/0050/kennis/kenn is_mobilelearning.pdf

[3] Rubens Wilfred, (2005) Didactische aspecten van mobile learning, Expertisecentrum ICT in het onderwijs, IVLOS, http://www.te-learning.nl/didaspmlearning.pdf

[4] Eindrapport - Final report, (2008), http://ewivlaanderen.be/documenten/eindrapport_startonderzoek 2001.pdf
[5] Knelpuntberoepen- Bottleneck professions, (2000), http://vdab.be/trends/maandverslag/topic 09.pdf

\section{AUTHORS}

Ruben Jans is lecturer and researcher at Limburg Catholic University College , 3590 Diepenbeek, Belgium (e-mail: ruben.jans@khlim.be).

Valère Awouters, is lecturer and researcher at Limburg Catholic University College , 3590 Diepenbeek, Belgium (e-mail: valere.awouters@khlim.be).

The article was modified from a presentation at the ICBL2008 conference held in November 2008 in Florianópolis, Brazil. Manuscript received 02 December 2008. Published as submitted by the authors. 